\title{
The Globalization in the actual Context of the European Union Economy
}

\author{
Mihai PĂUNICĂ \\ The Bucharest University of Economic Studies, Bucharest, Romania \\ mihai.paunica@cig.ase.ro \\ Alexandru MANOLE \\ "Artifex" University of Bucharest, Bucharest, Romania \\ alexandru.manole@gmail.com \\ Cătălina MOTOFEI \\ The Bucharest University of Economic Studies, Bucharest, Romania \\ cmotofei@yahoo.com

\begin{abstract}
Gabriela Lidia TĂNASE
The Bucharest University of Economic Studies, Bucharest, Romania

gabriela.tanase@cig.ase.ro
\end{abstract}

\begin{abstract}
In this paper, the authors aim to realize an in-depth analysis of the current characteristics of the globalization phenomenon from the viewpoint of the European Union and Romanian economy. The study will pursue some of the globalization indicators published by Eurostat, their status and a multidimensional perspective on their evolution. Namely, the foreign trade, the foreign direct investments, the employment, value added shall be subjected to analysis. The authors will apply statistical and econometric techniques to outline the behavior of economic globalization, depending on the values and dynamics of the support indicators. The structural and dynamic evaluation shall consider the main aspect of the multi-dimensional perspective, the geographical dimension. Both statistical and econometric tools applied lead to a set of conclusions, either general or subject-oriented, which show the present impact and trends of globalization in the European Union and Romanian economic activity. The research question was focused on how strong is the influence of globalization indicators on the economic growth for European Union and Romania. The results outline the behavior of the globalization indicators in the recent period, with focus on the effects of the economic crisis. The main indicators considered were the net export, import, export and the foreign direct investments, and their impact of the Gross Domestic Product is also revealed.
\end{abstract}

Keywords: globalization, indicators, regression, dimension, trend.

\section{Introduction}

The globalization is a phenomenon that has a significant impact on the global economy. The authors aim to capitalize the informational value of official statistical data, as explained in the methodology section, in order to emphasize the size and behavior of economic globalization indicators. By applying regression method, we aim to measure the influence of the most important of those indicators on the Gross Domestic Product, as the most appropriate measure of economic status and evolution.

Our main research hypothesis is the fact that, for the geographical and time dimensions described, the economic growth is influenced by the levels of the economic globalization indicators. Thus, by applying the statistic and econometric methodology, we 
will aim to measure the intensity of those influences, considering the independent variables related to globalization indicators.

Two key factors are among the most important criteria in the scope of globalization in economy, they are the foreign trade and the foreign direct investments. They help to measure the exposure of the national economy in a globalized environment. Furthermore, the impact they pose on the Gross Domestic Product forms additional evidence in measuring this exposure.

\section{Literature review}

Dima (2016) and Miron et al. (2010) develop on correlations between globalization, trade openness, and foreign direct investments in Romania, outlining that the foreign direct investments have influenced the globalization phenomenon in our country, other significant impact outlined refers to the level of trade openness as factor, while, in turn, Romanian foreign trade has evolved under the favorable influence of the globalization dynamics.

Melin (2004) states that globalization, expansion of markets and new competitors can be considered factors of influence for the international trade, he also outlines the evolution of international trade environment: the multinational companies, intra-regional transactions. Turtureanu and Ivan (2012) evaluate the impact of foreign direct investments on the foreign trade in Romania, they pay peculiar attention to the link between Foreign Direct Investments and competitiveness of export, discovering that, for the analyzed dataset, the correlation is strong and directly proportional. Metulini, Riccaboni, Sgrignoli and Zhu (2017) approach the network perspective in the correlation between trade and foreign direct investments, and offer solid empiric evidence on the characteristics of this interconnection.

Miśkiewicz and Ausloos (2006) have investigated the case of the richest 19 countries, by studying the growth of their Gross Domestic Products, thus they were able to outline the effects of globalization manifested under the form of economic correlations between those countries, a valuable result achieved by the two researchers is the fact that correlation becomes stronger across time. Prodan et.al. (2014) discuss the economic situation of Romania under the impact of crisis, their study results in a set of measures proposed for reversing the downward trend and getting on the path to economic recovery, they refer to the situation of the foreign trade and foreign direct investments in the Romanian economic context.

Krajišnik and Žutić (2017) develop on the impact of EU enlargement on the foreign trade and development of new members, reaching the positive effects on the new members admitted into the European Union within the fifth and biggest enlargement. The authors also realize a detailed analysis on the impact of foreign trade on the economic growth of these countries. Van Reenen (2017) evaluates the perspectives of globalization in the wake of US presidential elections' results in 2016, and of the BREXIT favorable vote, without passing over the similar populism-related movements in other European countries and, while considering the current status, expresses the hope for future progress in the development of free trade. Esposito (2017) provides useful evidence in the scope of researching the impact of euro on trade. Dudu and Moscu (2016) develop a complex analysis of the Gross Domestic Product by using linear multiple regression. 


\section{Methodology}

The research methodology is based on statistical and econometric tools for data analysis on the economic globalization indicators. The data source is the Eurostat online database (ec.europa.eu/Eurostat), the datasets related to these indicators. The software used for data processing is gretl (http://gretl.sourceforge.net/). The datasets analyzed include indicators related to:

- international trade;

- foreign direct investments (measured by Financial account, Direct investment, In the reporting economy indicator);

- employment, reflected by Employment in foreign controlled enterprises as a share of total domestic employment (Eurostat code [tps00004]), described as “(...)the share of employment held by foreign controlled enterprises in the reporting country divided by the total employment in the reporting country." (Eurostat indicator description);

- value added, measured by Value added in foreign controlled enterprises as a share of total value added, Eurostat code [tec00024], representing “...the share of value added held by foreign controlled enterprises in the reporting country divided by the total value added in the reporting country." (Eurostat indicator description).

We shall analyze the dynamics of these indicators for the European Union (EU28 and Euro Area 19) and Romania, to outline the position of Romania within the European context. The reference time period will cover, depending on the availability of data for individual indicators, the interval between 1995 and 2016. Also, we shall employ the simple and multiple regression methods, to test the influence of selected indicators on the economic growth, namely the Gross Domestic Product, expressed at market prices in the scope of our analysis.

The regression method, in its simple form, was described, among other authors, by Kowal (2016). The model involves the following parameters:

- a dependent variable;

- an independent variable;

- the structural parameters;

- the random component.

The case of multiple regressions involves more independent variables, whose influences on the dependent one is estimated based on the values of their respective parameters.

We shall define the equation for each proposed model and use the gretl software to estimate the parameters of the model, on the datasets pertaining to the two variables.

\section{Results and discussions}

The first step in our analysis involved the comparative study of the evolution of the Gross Domestic Product, for the interval 1995-2016, data with annual frequency. The data were drawn from the Eurostat database, for the three geographic coordinates. The figure below details the evolutions of the three measures: 


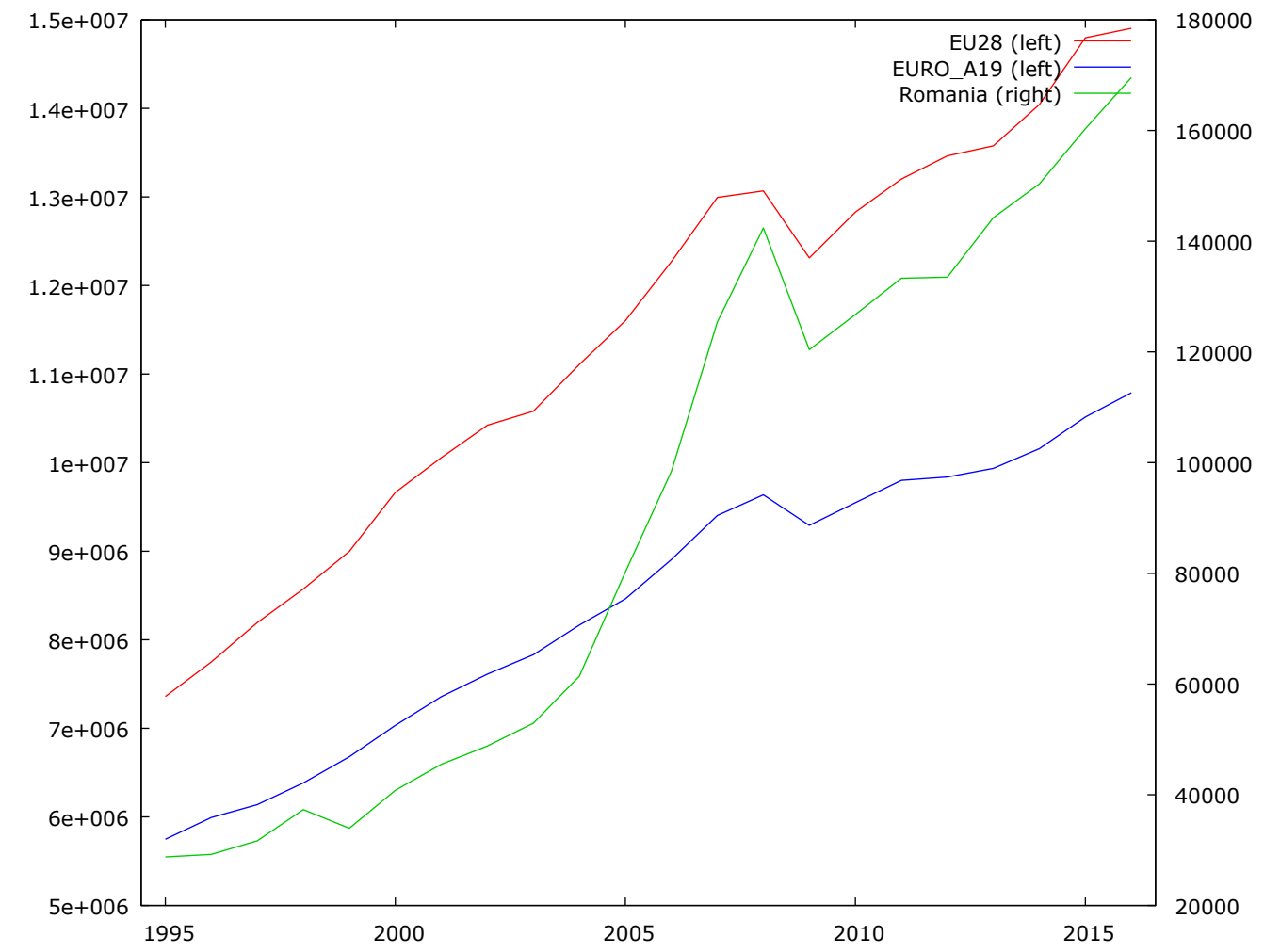

Figure 1. Comparative evolutions of Gross Domestic Products in Euro28 area, Eurozone 19 area and Romania

Source: authors' representation in gretl, data source Eurostat online database, dataset GDP and main components (output, expenditure and income) [nama_10_gdp], extracted Nov 30, 2017.

In the figure above (we outline that the scale for Romania is on the right vertical axis), there can be observed the relative similar patterns that characterize the evolutions of the respective GDP measures, even if Romania became member of the European Union in 2007 and is not member of the Euro monetary union area. The comparison between the Romanian and EU28 values of Gross Domestic Product, by percentage ratio (GDPR/GDP28) reveals an increase of Romania's share in the European Union 28 GDP, as during the period 1995-2003, this ratio is at most $0.50 \%$, it rises over $1 \%$ in 2008 (one year after the admission in the European Union), it keeps around 1\% during the interval 2009-2012, followed by a steady increase by 2016, when it reaches the maximum of $1.14 \%$.

As the Gross Domestic Product is the indicator that characterizes the economic growth in the framework of our study, we shall seek to validate the declared research hypothesis taking this indicator as dependent variable in regression models. There is a visible positive spike before the start of the economic crisis in 2008, followed by a sharp decline, and then a recovery trend that continues across the following years, until the end of the available dataset.

The next step involves the analysis of the foreign trade indicators' influence on the Gross Domestic Product. The import and export are components of the GDP by the expenses method, but our estimation shall try to measure the actual intensity of the impact for the considered interval, and in the model we shall, first, merge the two independent variable into one, which is the net export, considered as difference between export and import.

DOI: $10.2478 /$ picbe-2018-0066, pp. 739-750, ISSN 2558-9652| Proceedings of the $12^{\text {th }}$ International Conference on Business Excellence 2018 
The comparative evolutions of the two indicators (GDP, net export) are presented in the following figure:
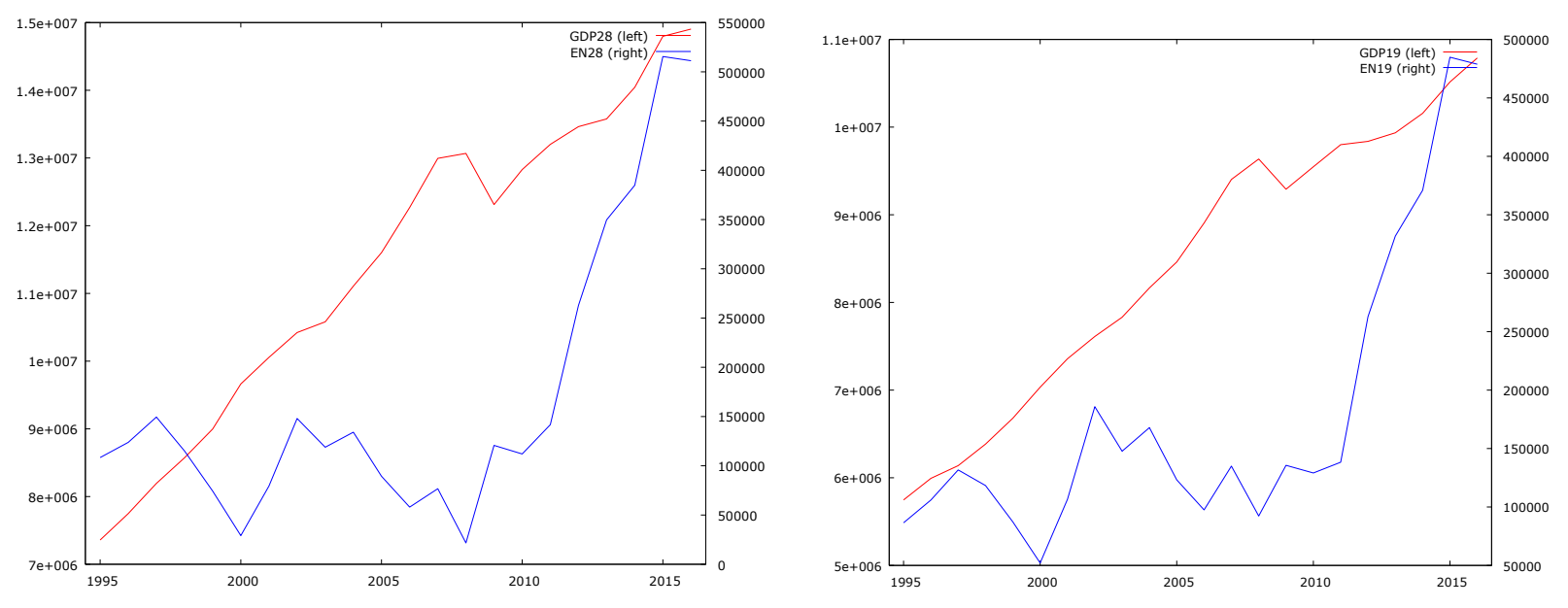

PICBE | 743

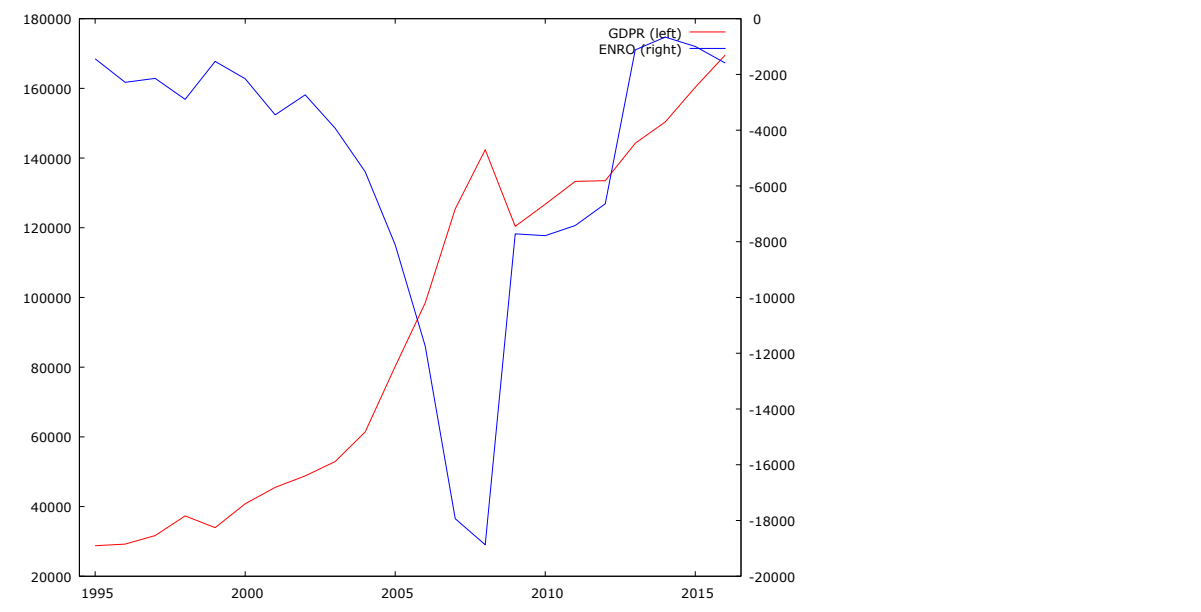

Figure 2. Comparative evolutions of Gross Domestic Products and net export in Euro28 area (first line, left), Eurozone 19 area (first line, right) and Romania (second line)

Source: authors' representation in gretl, data source Eurostat online database, dataset GDP and main components (output, expenditure and income) [nama_10_gdp], extracted Nov 30, 2017.

The above figure does not display a clearly visible linear correlation between the GDP and net export, in all cases there can be observed a rather oscillatory trend of the independent variable, which does not follow the trend of the Gross Domestic Product. In Romania, the net export recorded negative values across the entire interval, with a major decline in the 2006-2008 years, the very period preceding the impact of the effects of global recession on its national economy. For the European indicators as well, both EU28 and Eurozone 19 areas, a downturn spike is observed at the same moment corresponding to the occurrence of the economic crisis, followed by a significant recovery trend, also, let us take into account that the net export increases steadily, with a shift in the trend in 2016 (the net export decreases if compared to the 2015 reference value). It would be interesting to monitor the evolution of those indicators in 2017 and the years to come.

To have a clear picture of the correlation between the two indicators, we shall make use, as stated before, of simple regression, in which the GDP is dependent variable with the

DOI: $10.2478 /$ picbe-2018-0066, pp. 739-750, ISSN 2558-9652| Proceedings of the $12^{\text {th }}$ International Conference on Business Excellence 2018 
net export in the position of independent variable. The results of the estimations are presented in the figure no. 3 (based on ordinary least squares):

\begin{tabular}{|c|c|c|c|c|c|c|}
\hline & coefficient & std. & . error & t-ratio & \multicolumn{2}{|l|}{ p-value } \\
\hline \multicolumn{7}{|c|}{ 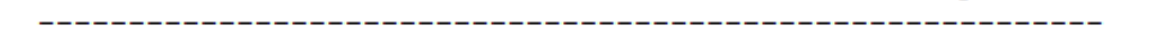 } \\
\hline 9.8138 & $9.81388 e+06$ & \multicolumn{2}{|c|}{636818} & 15.41 & $1.46 e-012$ & $\star \star \star$ \\
\hline 9.6273 & 9.62737 & & 2.90009 & 3.320 & 0.0034 & $\star \star \star \star$ \\
\hline Mean dependent var & \multicolumn{2}{|c|}{11443807} & \multicolumn{2}{|c|}{ S.D. dependent var } & \multicolumn{2}{|l|}{2311864} \\
\hline \multirow{2}{*}{$\begin{array}{l}\text { Sum squared resid } \\
\text { R-squared }\end{array}$} & \multicolumn{2}{|c|}{$7.24 e+13$} & \multicolumn{2}{|c|}{ S.E. of regression } & \multicolumn{2}{|l|}{1902169} \\
\hline & \multicolumn{2}{|c|}{0.355260} & \multicolumn{2}{|c|}{ Adjusted R-squared } & \multicolumn{2}{|l|}{0.323023} \\
\hline $\begin{array}{l}\text { R-squared } \\
F(1,20)\end{array}$ & \multicolumn{2}{|c|}{11.02027} & \multicolumn{2}{|c|}{ P-value (F) } & \multicolumn{2}{|l|}{0.003418} \\
\hline Log-likelihood & \multicolumn{2}{|c|}{-348.2554} & \multicolumn{2}{|c|}{ Akaike criterion } & \multicolumn{2}{|l|}{700.5107} \\
\hline \multirow{2}{*}{$\begin{array}{l}\text { Schwarz criterion } \\
\text { rho }\end{array}$} & \multicolumn{2}{|c|}{702.6928} & \multicolumn{2}{|c|}{ Hannan-Quinn } & \multicolumn{2}{|l|}{701.0247} \\
\hline & \multicolumn{2}{|c|}{0.844437} & \multicolumn{2}{|c|}{ Durbin-Watson } & \multicolumn{2}{|l|}{0.142244} \\
\hline
\end{tabular}

Model 2: OLS, using observations 1995-2016 ( $\mathrm{T}=22$ )

Dependent variable: GDP19

\begin{tabular}{|c|c|c|c|c|}
\hline & coefficient & std. error & t-ratio & p-value \\
\hline- & - & --- & ------ & --ー---ー-- \\
\hline const & $6.88383 e+06$ & 465397 & 14.79 & $3.12 e-012$ \\
\hline EN19 & 8.50761 & 2.13748 & 3.980 & 0.0007 \\
\hline
\end{tabular}

$\begin{array}{lrlr}\text { Mean dependent var } & 8419079 & \text { S.D. dependent var } & 1595734 \\ \text { Sum squared resid } & 2.98 e+13 & \text { S.E. of regression } & 1221444 \\ \text { R-squared } & 0.441996 & \text { Adjusted R-squared } & 0.414096 \\ \text { F(1, 20) } & 15.84207 & \text { P-value(F) } & 0.000737 \\ \text { Log-likelihood } & -338.5102 & \text { Akaike criterion } & 681.0204 \\ \text { Schwarz criterion } & 683.2025 & \text { Hannan-Quinn } & 681.5345 \\ \text { rho } & 0.856219 & \text { Durbin-Watson } & 0.170725\end{array}$

Model 3: OLS, using observations 1995-2016 ( $\mathrm{T}=22$ )

Dependent variable: GDPR

$\begin{array}{lcccc} & \text { coefficient } & \text { std. error } & \text { t-ratio } & \text { p-value } \\ \text { const } & 74044.5 & 15266.6 & 4.850 & 9.71 \text { e-05 k* } \\ \text { ENRO } & -3.08768 & 2.06874 & -1.493 & 0.1512\end{array}$

$\begin{array}{lrll}\text { Mean dependent var } & 90695.33 & \text { S.D. dependent var } & 50290.99 \\ \text { Sum squared resid } & 4.78 \mathrm{e}+10 & \text { S.E. of regression } & 48882.42 \\ \text { R-squared } & 0.100221 & \text { Adjusted R-squared } & 0.055232 \\ \text { F(1, 20) } & 2.227683 & \text { P-value(F) } & 0.151164 \\ \text { Log-likelihood } & -267.7060 & \text { Akaike criterion } & 539.4121 \\ \text { Schwarz criterion } & 541.5942 & \text { Hannan-Quinn } & 539.9261 \\ \text { rho } & 0.993018 & \text { Durbin-Watson } & 0.036411\end{array}$

Figure 3. Estimation of influence on Gross Domestic Products by net export in Euro28 area (first line), Eurozone 19 area (second line) and Romania (third line)

Source: authors' processing in gretl, data source Eurostat online database, dataset GDP and main components

(output, expenditure and income) [nama_10_gdp], extracted Nov 30, 2017.

DOI: 10.2478/picbe-2018-0066, pp. 739-750, ISSN 2558-9652| Proceedings of the $12^{\text {th }}$ International Conference on Business Excellence 2018 
The results of the models' estimations confirm the visual analysis on figure 2 charts, respectively the low correlation, on long term, between the net export and the Gross Domestic Product. One conclusion that results from this is the fact that import and export for each geographical area considered did not have a linear evolution across the considered interval, and not in convergence with the dynamics of the GDP, inducing also the presence of other factors which exerted stronger impact on the main indicator. This element is supported also by the values of const term, compared to the coefficient of the independent variable. Under the terms of the models, in EU28, an increase by unit of the net export shall lead to an additional value of GDP of more than 9.6 units, a similar influence is present in the case of Euro area 19, with more than 8.5 euros of GDP growth for each additional euro obtained from excess export. In Romania, however, the net export indicator has a negative influence, and not non-significant, as its values are negative. To be noted, the low values of the Durbin-Watson statistic, for all three models, meaning that the reliability or further applications of those regressions can produce not so accurate results. Based on the values of the log-likelihoods, the model of Romania has the best parameter in this respect.

To further investigate, we shall approach the evaluation of the separate impact of export and import on the GDP, by using the simple regression method and estimating individual models for each case.

The estimated parameters are presented in the table below:

Table 1. Influence of export import on the GDP, parameters of the simple regression models

\begin{tabular}{|l|c|c|c|c|c|c|}
\hline $\begin{array}{l}\text { Geographical } \\
\text { dimension }\end{array}$ & $\begin{array}{c}\text { Import } \\
\text { Coefficient }\end{array}$ & $\begin{array}{c}\text { Constant } \\
\text { for import }\end{array}$ & $\begin{array}{c}\boldsymbol{R}^{\mathbf{2}} \text { for } \\
\text { import }\end{array}$ & $\begin{array}{c}\text { Export } \\
\text { coefficient }\end{array}$ & $\begin{array}{c}\text { Constant } \\
\text { for export }\end{array}$ & $\begin{array}{c}\boldsymbol{R}^{\mathbf{2}} \text { for } \\
\text { export }\end{array}$ \\
\hline EU28 & 1.73279 & 4392210 & 0.982481 & 1.61216 & 4610170 & 0.973576 \\
\hline Euro zone 19 & 1.64388 & 3452460 & 0.977348 & 1.49496 & 3632630 & 0.966472 \\
\hline Romania & 2.30630 & 6069.55 & 0.984763 & 2.36538 & 16657.4 & 0.933213 \\
\hline
\end{tabular}

Source: authors' processing in gretl, data source Eurostat online database, dataset GDP and main components (output, expenditure and income) [nama_10_gdp], extracted Nov 30, 2017.

The results of the OLS estimation show the strong influence of export and import, considered as individual independent factors, on the Gross Domestic Product, supported by the high values of $\mathrm{R}^{2}$ coefficients. In all six models, the value of the constant term is significantly high, compared to the coefficients for imports and exports, which sustains the existence of other factors, derived from the expenses method of GDP calculation, but also from other macroeconomic correlations. The impact of the foreign trade on the European Union shows one side of the globalization influence on the EU28 economy. To be observed that each increase of the export by one Euro is mirrored by the growth of GDP by more than 1.61 Euros, and the import has an even more sizable influence.

The next part of our analysis will cover the status of foreign direct investments. The geographical dimension will cover the EU28 and Romania, for which comparable data exist. The comparative evolutions of the FDI and GDP in the EU28 and the Romanian economy, expressed in millions EUR/ECU, are presented in the following chart: 

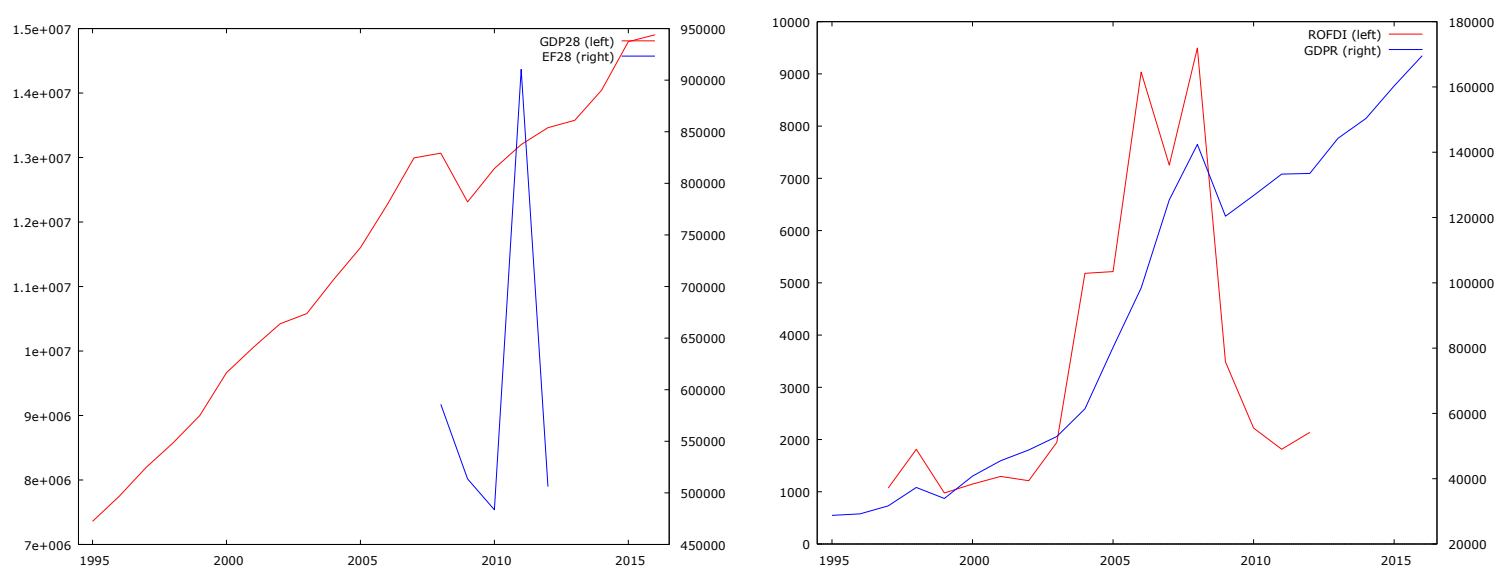

PICBE | 746

Figure 4. Comparative evolution of FDI indicator and Gross Domestic Products in Euro28 area (left), and Romania (right)

Source: authors' processing in gretl, data source Eurostat online database, datasets GDP and main components (output, expenditure and income) [nama_10_gdp] and EU direct investments - main indicators

[bop_fdi_main], extracted Nov 30, 2017.

As the data available for EU28 are limited, we shall focus on interpreting and further analyzing the situation of the Romanian economy. For the European Union, there are two major shifts in the evolution trend, both in 2010 and 2011. In Romania, the recent trend, posed by the FDI indicator, is encouraging, as it shows a slight increase; also the most recent downturn occurred simultaneously with the economic crisis. The Gross Domestic Product is on an upward trend.

There is some resemblance between the evolution pattern of FDI and GDP; however a better insight can be obtained by applying an econometric model. The estimation of the single regression model, having GDP as dependent variable and the FDI as factor variable, is presented in figure 5:

\begin{tabular}{|c|c|c|c|c|c|}
\hline & coefficient & sto & error & t-ratio & p-value \\
\hline \multicolumn{6}{|c|}{-------------------------------------------------------- } \\
\hline const & 55120.3 & \multicolumn{2}{|c|}{14675.0} & 3.756 & 0.0021 \\
\hline ROFDI & 7.79222 & & 3.29681 & 2.364 & 0.0331 \\
\hline Mean dependent var & \multicolumn{2}{|c|}{82050.17} & \multicolumn{2}{|c|}{ S.D. dependent var } & 42273.72 \\
\hline Sum squared resid & \multicolumn{2}{|c|}{$1.92 \mathrm{e}+10$} & \multicolumn{2}{|c|}{ S.E. of regression } & 36994.61 \\
\hline R-squared & \multicolumn{2}{|c|}{0.285220} & \multicolumn{2}{|c|}{ Adjusted R-squared } & 0.234164 \\
\hline$F(1,14)$ & \multicolumn{2}{|c|}{5.586435} & \multicolumn{2}{|c|}{ P-value (F) } & 0.033096 \\
\hline Log-likelihood & \multicolumn{2}{|c|}{-189.9312} & \multicolumn{2}{|c|}{ Akaike criterion } & 383.8624 \\
\hline \multirow{2}{*}{ Schwarz criterion } & \multicolumn{2}{|c|}{385.4076} & \multicolumn{2}{|c|}{ Hannan-Quinn } & 383.9415 \\
\hline & \multicolumn{2}{|c|}{0.977933} & \multicolumn{2}{|c|}{ Durbin-Watson } & 0.181574 \\
\hline
\end{tabular}

Figure 5. Estimation of influence on Gross Domestic Products by direct investments in Romania

Source: authors' processing in gretl, data source Eurostat online database, datasets GDP and main components (output, expenditure and income) [nama_10_gdp] and EU direct investments - main indicators [bop_fdi_main], extracted Nov 30, 2017. 
The R-squared and Adjusted R-squared tests' values display a low intensity correlation for the two indicators in the case of Romania. Furthermore, the constant term is more than 7000 times higher than the Foreign Direct Investments factor parameter, outlining, as in the previous case, a collection of additional factors, not considered in the scope of the model, which have a considerable impact on the economic growth, as reflected by GDP, an impact that is positive on the overall. The estimation offers a low value of the Durbin-Watson statistic, supporting the conclusion that the model should rise questions and concerns about its accuracy and reliability in further studies based on econometric methods. The log-likelihood, however, is highest than the levels corresponding to the models previously described.

The analysis of the EU28 situation, based on the data available, shows a sharp downfall in 2009 and 2010, when FDI dropped by more than 17\% compared to 2008. In 2011 , the situation improved greatly, with an amount of the indicator almost twice than the lowest value mentioned, in 2010. This means the beginning of the recovery from the late crisis, whose negative effects were felt also at the level of foreign direct investments.

As for the situation of employment indicators, the selected indicator, analyzed for Romania, displays a value close to one quarter from the total domestic employment, which shows another measure of the relatively high exposure to globalization effects, that is between a fifth and a fourth part of Romania's employees are working for a foreign controlled company. The dynamics of this indicator does not pursue the pattern of foreign direct investments, but is shown to have "incorporated" a smaller amount of crisis effects.

In Romania, the foreign companies contribute, across the interval for which data are available, with some $40 \%$ of the value added, the contribution measured is amongst the greatest in the European Union (see the chart in figure 6):

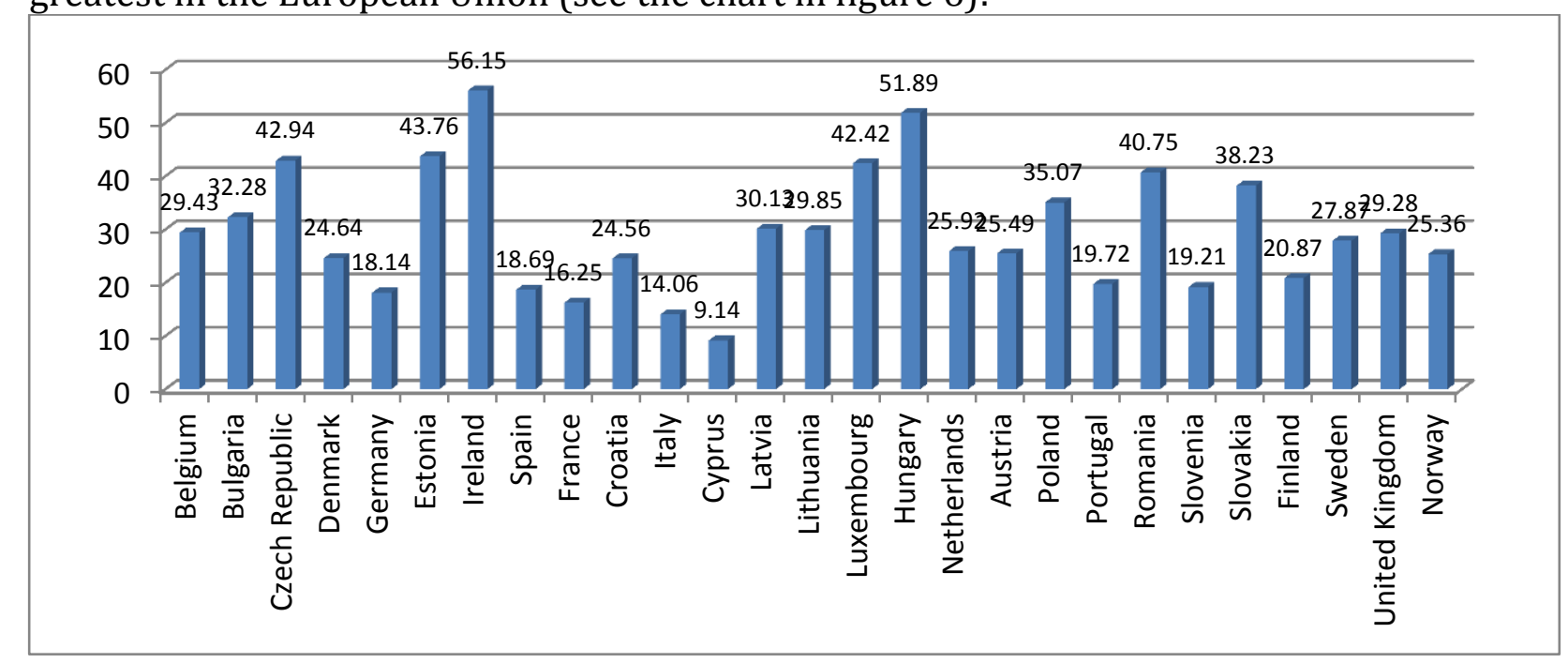

Figure 6. Comparative Value added in foreign controlled enterprises as a share of total value added, in 2011

Source: authors' processing, data source Eurostat online database, dataset Value added in foreign controlled enterprises as a share of total value added [tec00024], extracted Nov 30, 2017.

The strongest position is placed well above 50\%, corresponding to Ireland, also the second is found above that mark, which is Hungary. The average percentage for the entire 
dataset is, for 2011, 29.33, a value which reflects a considerable impact of foreign controlled enterprises on the value added in the European Union countries.

It can be observed that Romania holds the $6^{\text {th }}$ position across the dataset, which is a favorable sign, in the context in which the recovery from crisis was still at its beginnings in 2011. The value of the indicator is higher for Romania than Slovakia, Slovenia, Poland, Lithuania, Croatia, Czech Republic and Bulgaria.

Considering the results of the analyses, we consider, for Romania, the opportunity to evaluate, by applying multiple regression, the overall impact of the two most important factors outlined by the previous sections, namely the foreign trade indicators (import and export) together with the foreign direct investments, as reflected by Direct investment, In the reporting economy.

The comparative evolutions of the three indicators are presented in the chart below:

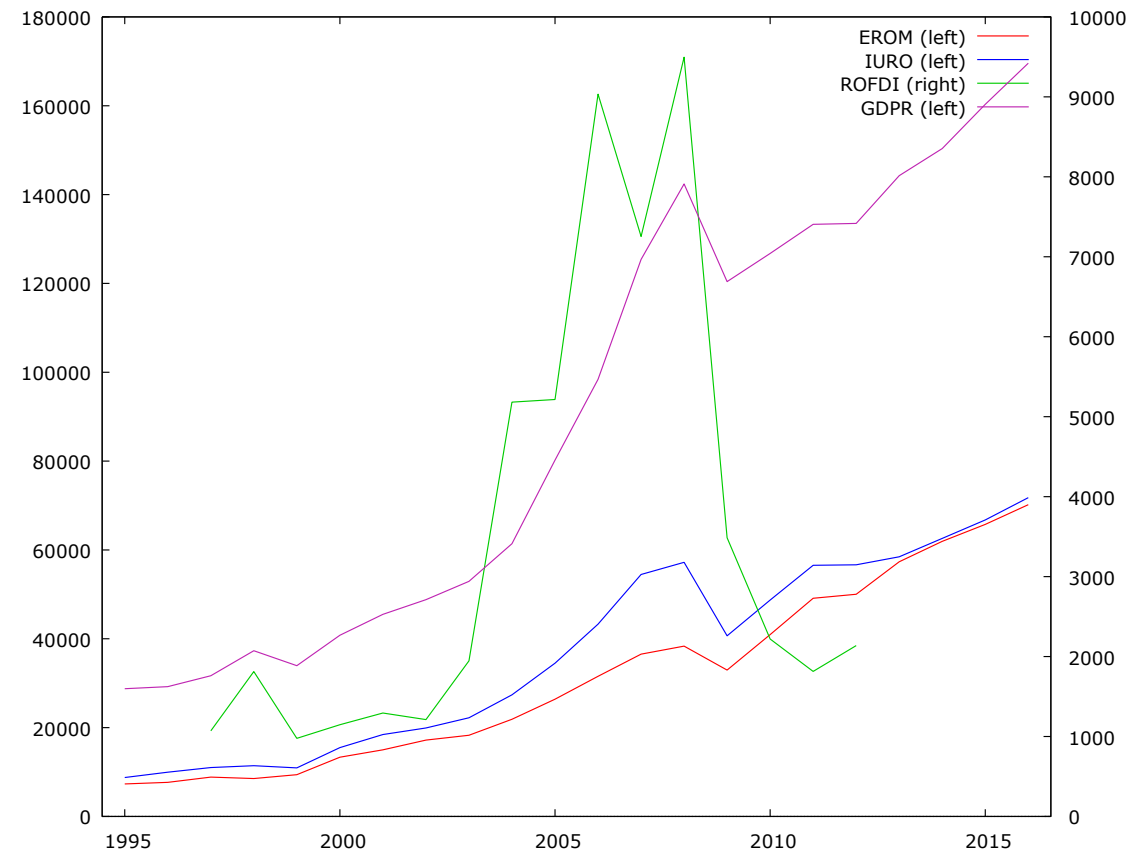

Figure 7. Comparative evolution of FDI, export, import indicators and Gross Domestic Products in Romania

Source: authors' processing in gretl, data source Eurostat online database, datasets GDP and main components (output, expenditure and income) [nama_10_gdp] and EU direct investments - main indicators [bop_fdi_main], extracted Nov 30, 2017.

The chart outlines the similarities between the evolution of GDP and foreign trade indicators, with little similarity regarding the FDI indicator's dynamics when compared to the main indicator. The estimation by multiple regression of the correlations between the four indicators is shown in figure no. 8: 


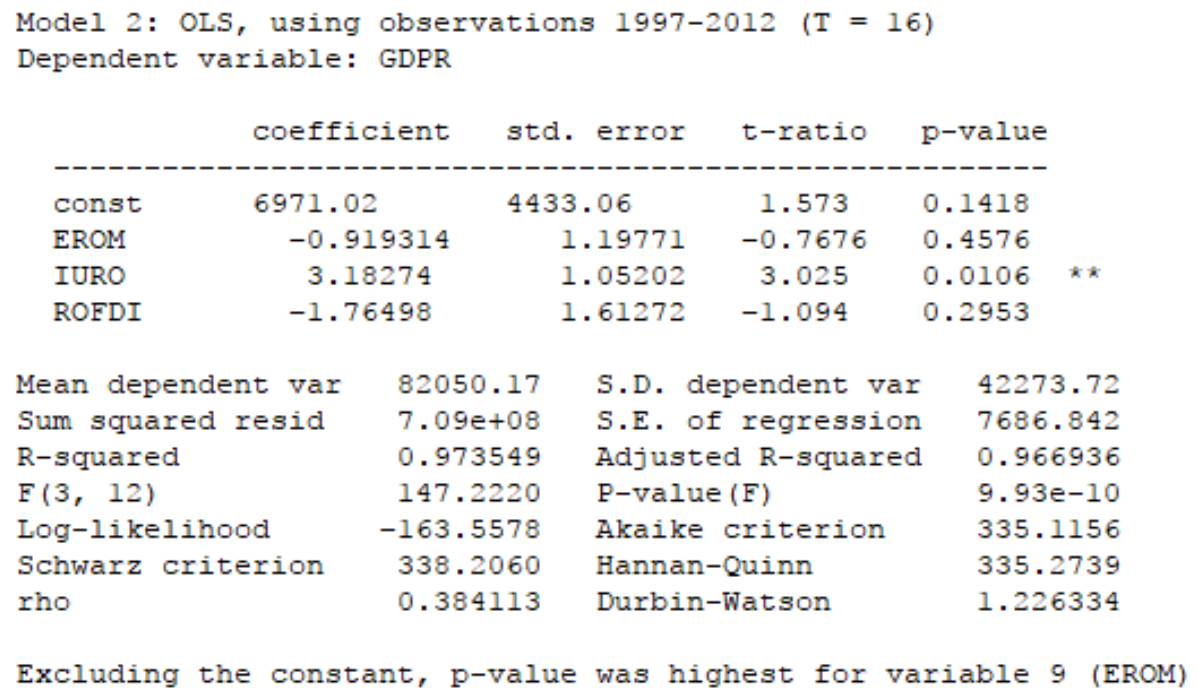

\section{Figure 8. Estimation of influence on Gross Domestic Product by FDI, export, import indicators in Romania}

Source: authors' processing in gretl, data source Eurostat online database, datasets GDP and main components (output, expenditure and income) [nama_10_gdp] and EU direct investments - main indicators [bop_fdi_main], extracted Nov 30, 2017.

The tests associated with the model are close to unit, well above 0.966 , showing that the model is reliable in judging the impact of the factors on the dependent variable. Also, the combined study of the three factors shows the dependence of GDP growth in Romania on import, with the export and FDI measures having negative influences. Also, in this case, the value of the free parameter is very high in comparison to the three parameters associated with the independent variables. This result is consistent with the previous model, detailed in figure 3. The Durbin-Watson statistic's level is a sign of proper reliability, as the value resulting from the estimation is closer to 2 than to 0 , while the log-likelihood is the highest from all models designed within this article. Thus, we consider the model is solid enough to be considered as it is, and also to be used in subsequent studies regarding the correlation between the four indicators in the form of GDP's dependency on the other three (independent) variables.

\section{Conclusion}

The results of our analyses show clearly that both the European and Romanian economies are subjected to globalization influences, at least from the viewpoints emphasized by the indicators we have presented. While running detailed studies on the case of foreign trade indicators and Foreign Direct Investments, we have outlined the influences posed by these indicators on the economic growth in all cases. Some of the influences are positive, some are negative. The net export in Romania is negative for the entire interval subjected to analysis, so its impact on the Gross Domestic Product is not favorable, a situation reflected also by the last model, where the growth of the GDP is favorably influenced only by the imports, which is not a situation that is able to lead to development of Romania's exposure to international economic context in the long run. The development of the intra-border capacity to support the internal demand should contribute to the more sustainable development of the Romanian economy in the future. The comparison with the European

DOI: 10.2478/picbe-2018-0066, pp. 739-750, ISSN 2558-9652| Proceedings of the $12^{\text {th }}$ International Conference on Business 
Union and the Euro monetary area is a further concern in the scope of the net export influence, by taking into account that the situation is different, as the net export's increase leads to the increase of the Gross Domestic Product at market prices in the two areas. It would be ideal for Romania to reach the same situation in the near future, so to achieve a stronger position in the face of international economic challenges. Also, Romania's economic situation is influenced by globalization from the viewpoints of labor force attracted by foreign investors and the value added developed by foreign companies. As further research interest on the matter, the authors will pursue the expansion of the analysis to additional indicators and countries/geographical area in the European Union, in order to enrich the practical knowledge on the impact of globalization, mainly on economic growth, but also on other economic aspects.

\section{References}

Dima, S. (2016). Globalisation, Trade Openness and Foreign Direct Investment in Romania. Studia Universitatis „Vasile Goldis” Arad-Economics Series, 26(4), 41-53.

Dudu, L., \& Moscu, R. G. (2016). The Practical Use Of The Linear Multiple Regression In The Complex Gdp Analysis. Knowledge Horizons-Economics, 8(2). Retrieved from http://orizonturi.ucdc.ro/arhiva/KHE_V8_iss2_PDF_2016/KHE_V8_iss2_12\%20Ligia \%20Dudu_Raluca\%20Georgiana\%20Moscu.pdf

Esposito, P. (2017). Trade creation, trade diversion and imbalances in the EMU. Economic Modelling, 60, 462-472.

Kowal, R. (2016). Characteristics and Properties of a Simple Linear Regression Model. Folia Oeconomica Stetinensia, 16(1), 248-263.

Krajišnik, M., \& Žutić, A. (2017). Impact of the Enlargement of the European Union on the Foreign Trade and Development of the New Members. Economics, 5(1), 36-51.

Melyn, W. (2004). Characteristics and development of Belgium's foreign trade. Economic Review, (iii), 7-27.

Metulini, R., Riccaboni, M., Sgrignoli, P., \& Zhu, Z. (2017). The indirect effects of foreign direct investment on trade: A network perspective. The World Economy, 40(10), 2193-2225.

Miron, D., Dima, A.M. and Vasilache, S. (2010). Models of the Intra-regional Trade Influence on Economic Sustainable Development in Romania. Amfiteatru Economic, XI (27), pp. 27-35

Miśkiewicz, J., \& Ausloos, M. (2006). An attempt to observe economy globalization: the cross correlation distance evolution of the top 19 GDP's. International Journal of Modern Physics C, 17(03), 317-331.

Prodan, L., Grigorescu, C. J., \& Moscu, R. G. (2014). The Economical Situation of Romania During Crisis, European Integration and Globalization. Knowledge HorizonsEconomics, 6(1), 97-104.

Turtureanu, G. A., \& Ivan, M. A. (2012). FDI influence over Romanian exports. EuroEconomica, (3 (31)), 114-120.

Van Reenen, J. (2017). Brexit and the Future of Globalization?(No. 35). Centre for Economic Performance, LSE. Retrieved from http://cep.lse.ac.uk/pubs/download/special/cepsp35.pdf

ec.europa.eu/Eurostat. 